\title{
INTERCULTURAL COMPETENCES IN TRANSLATION \\ EDUCATION: A COLLABORATIVE TASK-BASED \\ APPROACH
}

Diana Prodanović Stankić, University of Novi Sad, Novi Sad, Serbia, diana.prodanovic.stankic@ff.uns.ac.rs

Helga Begonja, University of Zadar, Zadar, Croatia, hbegonja@unizd.hr

Original scientific article

DOI: 10.31902/fll.34.2021.18

UDC: 371.3:81'25

\begin{abstract}
Apstrakt: The aim of the paper is to report on the collaborative task-based case study that was organized bilaterally between the students at the University of Novi Sad and the University of Zadar, as a part of two translation courses, at the undergraduate and graduate level of studies. This study is part of some bigger research and the study presented in this paper has the following aims: to help the students gain intercultural competences by working collaboratively both in teams at the home university and online together with the students from the other country, using different virtual collaborative tools, and to face the challenge of organizing the translation project related to a specific task. Intercultural competences and the ability to cooperate are among the core competences that are required from a professional translator; however, these competences are not sufficiently covered by the learning objectives of curricula and syllabi at the university level. For that reason we wanted to focus on these competences to try to increase our students' employability prospects. The study was qualitative and quantitative, based on process and product analysis. We used observation, questionnaires and analysis of the final product of translation to collect the data for the study. The results point to benefits of this approach as well as to the areas that are in need of improvement in this field.
\end{abstract}

Key words: Translation education, collaboration, team work, intercultural competences, task-based approach

\section{Introduction}

Nowadays, most higher education institutions prioritize developing transversal skills of their students, in addition to the core competences and skills dependant on the given field of study, since they need to enhance their students' employability prospects as well as mobility in the global world. In this framework, intercultural competence plays a crucial role. As Kučiš points out, 
"international communication takes place between different cultures and for that reason this communication needs to be viewed from the perspective of democratic translational cultures, which, on the other hand, need to be ruled by principles of cooperation, loyalty, transparency and ecology, so as to avoid possible conflict"1 (65).

The intercultural competence seems to be even more relevant in curricula designed for educating prospective language professionals, teachers of foreign languages or translators, and one of the ultimate goals of foreign language education (Byram, 1997; Deardoff, 2009; Lázár et al.).

Nevertheless, defining intercultural competence is not always straightforward as it entails the concepts of culture and competence, both of which are elusive. First of all, in intercultural context, "culture is seen as a socially constituted set of various kinds of knowledge structures that individuals turn to as relevant situations permit, enable, and usually encourage" (Kecskes 4). Moreover, Kecskes (4) highlights the fact that culture has fuzzy boundaries, being neither relatively static nor ever-changing at the same time. In addition to that, culture typically implies heterogeneous properties, which makes the process of determining its specific elements even more complex.

Even though there are different approaches to defining the concept of intercultural competence, in this paper we will use the definition offered by Spitzberger and Changnon who state that "intercultural competence is the appropriate and effective management of interaction between people who, to some degree or another, represent different or divergent affective, cognitive, and behavioural orientations to the world" (7). This interaction is realized on the individual level even though it represents group conceptualisations. In addition to that, they state that "the extent to which individuals manifest aspects of, or are influenced by, their group or cultural affiliations and characteristics is what makes an interaction an intercultural process" (Spitzberger and Changnon 7). According to Byram (2000), intercultural competence implies that an individual "is able to understand critically or analytically that one's own and other cultures perspective is culturally determined, rather than natural" (9). Moreover, it allows people to interpret the relationships between different cultures and mediate adequately. In an attempt to explore and adequately assess intercultural competence, Fantini divides this

\footnotetext{
${ }^{1}$ Translation provided by the authors
} 
competence into knowledge, attitude, skills and awareness that someone may possess to greater or lesser extent in order to be intercultural competent. This division is quite useful in the educational context since it allows easier handling of specific teaching activities aimed at the given subdomain.

In Translation Education intercultural competences have always been in the focus, as translation by definition represents an act of intercultural communication (Newmark 2), which, as Katan (96) argues, implies a language transfer as well as transmitting cultural patterns conveyed by language. For that reason, Translation Education seems to be a fertile ground for fostering intercultural skills, though it can be argued how this competence can be developed systematically and later on, assessed adequately. Deardorff (2006) used empirical research in the attempt to find the most adequate ways to assess intentional development of learner's intercultural competence. According to the findings of her study (Deardorff 2006, 250-251), assessment is crucial as it guides successful implementation of activities that are part of syllabi and curricula of the given higher education institution. Among some specific methods, she (Deardorff 2006, 251) lists a mix of qualitative and quantitative measures through which intercultural competence can be assessed, particularly case studies and interviews, analysis of narrative diaries, self-report instruments, observation by others/host culture, and judgment by self and others.

This study is based on the assumption that intercultural competence can be developed through specific learning activities and tasks. Following Byram (2008, 60), who argues for the distinction between being bicultural and acting interculturally, we wanted to create an educational context in which mediation between different cultural areas can be learnt and practiced. For that reason, the aim of the study was to help the students gain intercultural competences by working collaboratively on a translation task using different online tools. This collaborative task-based study was organized bilaterally between the students at the University of Novi Sad and the University of Zadar, as a part of some bigger research project with the aim of getting a deeper insight into virtual collaborations of students. The main idea behind the project was to get the students who live and study in two different, but neighbouring countries and who speak very similar languages to think about the way their own and the target culture is rendered through the given language. For that reason, the study was done as a part of translation courses in which participants had to translate a poem from a book for children, Struwwelpeter, by Heinrich Hoffmann. We chose a children's book as a task for translation hoping that the students would 
not face many translation problems related to the use of language, but rather that they would need to draw on their creativity skills and cultural background to deal with the text. At the same time, as educators, we wanted them to experience a multicultural environment which they will face while working on similar translation projects once they graduate and start working as professional translators. Translated literature for children has a large share in publishing industry all over the world, including Croatia and Serbia. Unfortunately, translator education at tertiary level does not really follow this trend in the sense that most of the curricula at different universities in both countries do not include translating for children either at undergraduate or postgraduate levels of study. Certainly, translating for children implies specific competences and skills, thus, we wanted to give our students a chance to try to be creative and at the same time conscious of the target readers' needs, while trying to negotiate and reach the final solutions with their team members.

The aims of the project were the following: to help the students gain intercultural competences by working collaboratively both in teams at the home university and online together with the students from the other country, using different virtual collaborative tools, and to face the challenge of organizing the translation project related to a specific task. In the rest of the paper, we will give a brief overview of the theoretical framework related to the basic concepts, present the methodology and the data we got. After a discussion of the results, we will suggest some directions for further research.

\section{Intercultural Competence in Translation Education at the University Level}

Translation education is in most European universities organized either as a part of philology departments or separate departments devoted to Translation Studies, focusing on the practice of specific skills related to the process of translation. In most countries, the curricula that cover this field are designed and created according to European standards and frameworks (cf. Pym et al.). In essence, these standards and frameworks start from the idea that translation presupposes a complex engagement with meanings across languages and cultures (Bassnett; Katan 2004, 2013). As much as developing intercultural competence should not represent a separate element of a curriculum or specific syllabus, but rather be integrated in the learning process, this is often the case.

Byram (2008, 65) states that "acting interculturally" presupposes certain attitudes, knowledge and skills that need to be 
learnt" and focuses on the need that understanding and empathizing with the values of others requires a willingness to suspend one's own deeper values, at least temporarily. This is even more significant considering the fact that translation is a collaborative activity (Cordingley and Frigan Manning), even more so in the global market, in which collaboration and working on joint projects frequently includes intercultural teams and virtual collaboration.

In that context, the learning objectives that are part of the curricula are closely related to raising students' awareness in reference to the cultural aspects inherent in the text as well as the source and target language. Furthermore, students need to recognize their own position as translators-to-be in the complex network of cultural perspectives in the plurilingual environment. These processes are undoubtedly part of the concept of empowerment that was introduced in Translation Education by Kiraly. In essence, empowerment entails both the student's and the teacher's involvement in a "dynamic, interactive process based on learner's empowerment" in order to focus on learning as a "collaborative, acculturative, and quintessentially social activity" (Kiraly 18).

Kiraly draws on a social-constructivist approach, which implies that knowledge, competences and skills are not passed on from the teacher to students, but they are constructed through interpersonal interactions and collaboration. For that reason, it is up to those involved in the interaction to strike the perfect balance between theoretical and practical knowledge. This whole concept is very appealing and rational, however, it is a long term process that requires a lot of active engagement on the part of students and educators. Also, it has also some direct consequences on the creation of adequate assessment methods as the educators need to have a clear vision of what students need to know, be aware of and be able to do regarding intercultural aspects of translation.

Following González Davies, who argues that "translation can be used as both a skill and a strategy in an informed way" (162), the aim of this paper is to explore the possibilities of using a collaborative translation project in a twofold way: both as a method of developing specific translation skills and as a learning strategy aimed at improving our students' intercultural competences.

\section{Methodology}

\section{The Study}

This case study was conducted on the graduate level of studies at the Department of German Studies, University of Zadar, Croatia, and 
on the undergraduate level of studies at Department of English Studies, Faculty of Philosophy, University of Novi Sad, Serbia in the winter semester of the academic year 2017/2018. Since this study was a part of some bigger research that dealt with collaboration in translation, the specific aims of this study were the following:

1. to create virtual intercultural teams in order to observe the collaborative process of translation and learn more about the interpersonal, culture-specific and other factors that have an impact on the process of translation;

2. to explore the quality of the online interaction between the participants of the study in order to evaluate the quality of this learning experience by teachers' observation and students' perception of the whole process;

3. to make students focus on the elements of their own and the target language culture while translating and collaborating in order to develop their intercultural competences.

The study included 64 second-year students at the University of Zadar and the University of Novi Sad. The students in Zadar took the course Intercultural Communication and the students in Novi Sad Translation from Serbian into English. The study was organized in the winter semester 2017/2018. Out of the total of 64 participants, 32 were native speakers of Croatian, 27 native speakers of Serbian, 3 native speakers of Hungarian and 2 native speakers of Slovak.

The participants were asked to work in teams and they were allowed to pick their own team members and appoint team leaders and assign other team roles. There were eight groups of four students. Their task was to select and translate two texts from Hoffmann's Struwwelpeter. The students chose Die Geschichte vom bösen Friederich and Die Geschichte vom Zappel-Philipp, as the most relevant for today's children. The students had to read the whole book before translating the given poem in order to be fully acquainted with the overall context. First of all, the students at the University of Zadar translated the text from German into Croatian, and then, the students at the University of Novi Sad started from the Croatian version, and used it as a source for translating into English. When they had problems with the differences between Croatian and Serbian they solved that online with their colleagues from the University of Zadar. The students worked in small groups and their final work was evaluated later by another, control group of students. When needed, the students talked to each other and met in the virtual space via Skype or by the means of discussion groups 
and chats. The documents were also shared, revised and edited among the team members using Edmodo, Google Docs and Dropbox.

The study was qualitative and quantitative. Apart from observation, we used product analysis and questionnaires to obtain data for the study. While analyzing the translations that were done by students, we relied on the theoretical framework of Descriptive Translation Studies (DTS) (Toury). Desmidt (79) argues that within this approach, it is important to study translations in a descriptive way, without excluding any translated text from the corpus in advance if it does not meet a previously defined fixed and absolute checklist of features that it needs to possess. That implies that we analysed the versions our students provided as such, without correcting the errors, changes or adaptations they made, and in the context of our study, such translations served as an input or source texts for the other groups of students who translated the text from Croatian into English. Still, the specific constraint that we had was the fact that we were not able to test the reception of the translated text among the target readers, i.e. children and their parents in the given cultures, for the time being. For these reasons we needed some relevant criteria to evaluate and then to analyze the translations that we got from our students. Following Eraković, we used the standards of textuality as defined by de Beugrande and Dessler (cohesion, coherence, intentionality, acceptability, informativeness, situatedness, and intertextuality) in order to describe the given translations and compare the results.

The qualitative and quantitative analyses were carried out analysing the answers we got in a Likert scale type of a questionnaire. The questionnaire contained twelve statements and the scale of five point's agreement. The results were calculated using descriptive statistics based on the percentage share within the structures of the categories. The statements in the questionnaire reflected Fantini's suggestion that assessment of intercultural competence should focus on knowledge, attitude, skills and awareness.

\section{Results and Discussion}

The results of the study suggest that as much as students of foreign languages are aware of the concept of culture and different cultures, they still need to be empowered to "act interculturally" (Byram 2008). Also, translation-based tasks seem to be a good method for encouraging that empowerment, due to the fact that such tasks make the students focus on some translation problems related to cultural references in the given text, among other things, raising their awareness 
to comparing cultural elements between the source and target language and culture.

Observation of the activities and the task students had to do indicate that the students had clear ideas what is meant by culture in the theoretical sense and they did not have problems recognizing, identifying and later on dealing with the prototypical elements of culture as reflected in the task. For example, many teams decided to culturally adapt proper names in the target text, so that they fit the target culture and language, and the expectations of children as potential readers of these poems. Nevertheless, when they encountered less typical cultural references in the text, for example, rituals, or levels of formality in communication, they usually failed to notice them. This could be noticed in all teams, regardless of their native language. For that reason, they did not discuss these issues in their collaboration and focused more on some lexical or morphosyntactic difficulties in the text. Judging by their discussions or comments they left in the comments section in the documents they shared, culture and cultural adaptation was the least discussed topic and collaborative work that involved intercultural perspectives did not help in that respect. On the other hand, in terms of their own intercultural communication skills, all of them were very tolerant and willing to listen to the other team member, either in person or virtually, and none of the students reported any negative behaviour based on the ethnic background, even though their answers in the questionnaire indicate that sometimes some of the students felt that the other team members were too imposing in terms of their suggestions. Moreover, they used the intercultural framework to address some of the problematic, typically language-based issues in the sense that they would try to make some feedback less critical and harsh drawing on the argument that in the given culture, this is not acceptable.

As the results presented in Table 1 show, they found collaborative work rewarding and found the discussions they had with the students from the other country useful for the process of translation and the final end-result. Specifically, the students claimed that collaborative approach helped them find more creative solutions and think of more expressive ways of rendering some rhymes or idiomatic language found in the poems. Another beneficial aspect was time management as they were more efficient in total. At the beginning, some of the teams had problems with delegating specific tasks and assigning roles within a team, however, in their virtual interactions with other teams they did not show these problems. Also, they commented that it was easier for them to find answers for most problematic issues 
while working together and combining different perspectives. In addition to this, this affected involvement in the whole project. What should also be stressed is the fact that they said that they enjoyed working together and that it was fun, as much as the discussions they had were sometimes extended beyond the problems at hand, which, of course, had a negative consequence on managing smaller time units.

From the point of observers and researchers, we had problems with a relatively big number of students who were indecisive with their answers to most of the questions. On the one hand this can be explained with the fact that many of our students are accustomed and used to the traditional teaching methods are typically employed in Translation Education, which entail working individually on the assigned text and then taking part in the discussion that is in a way conducted by the teacher in most cases. Even though interactive and collaborative activities in the team may be useful and beneficial for the end product, it seems that many of our students do not like the responsibilities one needs to take when working in a team or sharing and arguing for one's opinion or solution in front of many people. Relying on the final feedback from the teacher, they still feel insecure regarding their own translation competences and skills.

Related to this, assessment is another element that needs to be considered in the ambivalent attitudes of students. At both universities, students are assessed at the end of the course individually, based on their own work and for that reason they tend to shy away from any activity that involves team or group work. Most of the time, they do not know how to organize themselves effectively in teams so as to create a working atmosphere that would benefit all, and intercultural groups only add to that confusion and insecurity.

Table 1 Students' attitudes (in percentages)

\begin{tabular}{lccccc}
\multicolumn{1}{c}{ Statement } & $\begin{array}{l}\text { Strongly } \\
\text { agree }\end{array}$ & $\begin{array}{l}\text { Partially } \\
\text { agree }\end{array}$ & $\mathrm{n} / \mathrm{a}$ & $\begin{array}{c}\text { Partially } \\
\text { disagree }\end{array}$ & Disagree \\
\hline $\begin{array}{l}\text { Collaborative } \\
\text { translation }\end{array}$ & 29 & 26 & 13 & 14 & 18 \\
with students & & & & & \\
from another & & & & & \\
faculty & & & & & \\
is a more & & & & \\
rewarding & & & & \\
activity than \\
doing it only
\end{tabular}


with your

colleagues

\begin{tabular}{|c|c|c|c|c|c|}
\hline $\begin{array}{l}\text { Discussing } \\
\text { solutions with } \\
\text { speakers of a } \\
\text { different } \\
\text { language } \\
\text { improves the } \\
\text { quality of the } \\
\text { translation }\end{array}$ & 28 & 37 & 9 & 16 & 10 \\
\hline $\begin{array}{l}\text { Working } \\
\text { collaboratively } \\
\text { in intercultural } \\
\text { teams we } \\
\text { came up } \\
\text { with better } \\
\text { solutions }\end{array}$ & 37 & 16 & 16 & 24 & 7 \\
\hline $\begin{array}{l}\text { Working } \\
\text { collaboratively } \\
\text { in intercultural } \\
\text { teams we } \\
\text { needed less } \\
\text { time to finish } \\
\text { the tasks }\end{array}$ & 41 & 29 & 7 & 9 & 14 \\
\hline $\begin{array}{l}\text { Feedback I got } \\
\text { from my } \\
\text { colleagues was } \\
\text { useful }\end{array}$ & 13 & 28 & 22 & 25 & 12 \\
\hline $\begin{array}{l}\text { The } \\
\text { discussions we } \\
\text { had were very } \\
\text { useful }\end{array}$ & 16 & 35 & 13 & 17 & 19 \\
\hline $\begin{array}{l}\text { Other team } \\
\text { member's } \\
\text { ideas } \\
\text { encouraged } \\
\text { me to } \\
\text { reconsider my } \\
\text { own solutions }\end{array}$ & 11 & 7 & 13 & 37 & 32 \\
\hline $\begin{array}{l}\text { Working } \\
\text { collaboratively } \\
\text { was } \\
\text { distracting me } \\
\text { from providing }\end{array}$ & 10 & 29 & 6 & 19 & 36 \\
\hline
\end{tabular}




\begin{tabular}{|c|c|c|c|c|c|}
\hline $\begin{array}{l}\text { Some team } \\
\text { members } \\
\text { imposed their } \\
\text { own solutions }\end{array}$ & 9 & 12 & 21 & 26 & 32 \\
\hline $\begin{array}{l}\text { The whole team } \\
\text { was very } \\
\text { productive }\end{array}$ & 31 & 24 & 13 & 14 & 18 \\
\hline $\begin{array}{l}\text { Team work is } \\
\text { more demanding } \\
\text { than working on } \\
\text { your own since } \\
\text { team members } \\
\text { have to accept } \\
\text { solutions that } \\
\text { they do not } \\
\text { completely agree } \\
\text { with }\end{array}$ & 15 & 23 & 6 & 31 & 25 \\
\hline $\begin{array}{l}\text { Translation that is } \\
\text { a result of team } \\
\text { work is better } \\
\text { than the one done } \\
\text { individually } \\
\text { because it } \\
\text { comprises more } \\
\text { ideas of different } \\
\text { people who } \\
\text { contributed to it }\end{array}$ & 29 & 14 & 15 & 31 & 11 \\
\hline
\end{tabular}

Another significant finding related to the concept of empowerment and the development of intercultural competences is the fact that intercultural and communication competences are closely related in the educational setting. Knowledge, awareness and attitudes that comprise intercultural competence are in this setting expressed through language and communicative competences and skills. In that sense, it seems that communicative competence as well as interpersonal skills affects the development of intercultural skills as well. Hence, preparing students to engage and collaborate in translation projects is not only related to the development of typical translation competences and skills but other skills as well, and it should be integrated into different kinds of assignments. Moreover, increasing empowerment and joint constructive work in collaboration leads to developing creativity, as a 
specific competence needed, particularly in translation of literature written for children.

Undoubtedly, it is the responsibility of educators to empower students to interact and work collaboratively and to create learning environment both in classroom and on online platforms in order to develop intercultural skills, since cooperation implies the need to negotiate, construct and understand cultural elements. For that purpose, translation can be used as an asset and a method for improving this competence. Using foreign languages and related cultures is a good framework for setting the ground as well as systematic inclusion of intercultural collaborative work in curricula and syllabi design.

\section{Conclusion}

The purpose of this paper was to address the development of intercultural competence in Translation Education at the tertiary level. Even though this competence is extensively written about in the relevant literature, particularly in terms of its significance for adequate functioning in the modern global world, there are many challenges related to the practical implementation of it in the educational context, which need further elaboration.

In this study, the aim was to create a specific translation assignment that will make the students work collaboratively and act interculturally. The students of two different universities in two countries, Croatia and Serbia, were connected in the virtual space to work together on a joint translation project which involved translation of two poems from a children's book. The main idea behind the study was to raise awareness of our students regarding intercultural cooperation and encourage them to shift the focus from the factual knowledge "about" the intercultural competence to practical "know how".

The results of the study indicate that the students did not have problems with knowledge and attitudes related to intercultural competence, however, they still needed encouragement and practical help regarding skills and awareness. In addition to that, it was shown that collaborative work through an intercultural dialogue helped them express their creativity in providing specific translation solutions. Nevertheless, the results of the study indicate that they still need more practice in the field of team management skills, negotiating and constructing their own arguments and feedback on other people's work.

Judging by the results of this study, there are many directions for further research that can be suggested. In the first place, the interrelationship of personal traits, motivation, individual learning 
experience and intercultural competence needs to be explored, since these factors seem to have the most significant impact on each other and also on assessment. Since the curricula at our universities do not include assessment of intercultural competences, it would be necessary to get a deeper insight into this issue so as to define better the framework for the development of this competence and create specific course content that can be used with that aim.

\section{References}

Bassnett, Susan. Translation studies. London: Routledge, 2013.

Byram, Michael. Teaching and assessing intercultural communicative competence. Bristol: Multilingual Matters, 1997.

Byram, Michael. "Assessing intercultural competence in language teaching." Sprogforum 18 (2000): 8-13.

Byram, Michael. From foreign language education to intercultural citizenship. Clevedon: Multilingual Matters, 2008.

Cordingley, Anthony, and Céline Frigau Manning (eds.). Collaborative Translation: From Renaissance to the Digital Age. London: Bloomsbury, 2017.

de Beugrande, Robert, and Wolfgang Dessler. Introduction to Text Linguistics. London: Longman, 1981.

Deardorff, Darla. "Identification and Assessment of Intercultural Competence as Student Outcome of Internationalization." Journal of Studies in Intercultural Education 1 (2006): 241-266.

Deardorff, Darla. (ed.). The Sage Handbook of Intercultural Competence. London: Sage, 2009.

Desmidt, Isabelle. "A Prototypical Approach within Descriptive Translation Studies? Colliding Norms in Translated Children's Literature." Children's Literature in Translation: Challenges and Strategies. Ed. Jan van Coillie, and Walter P. Verschueren. London and New York: Routledge, 2006. 7997.

Eraković, Borislava. "Prevođenje knjiga za decu: problem strategije." Encounter of cultures II. Ed. Ivana Živančević Sekeruš. Novi Sad: Faculty of Philosophy, 2013. 789-799.

Fantini, Alvino. Exploring and Assessing Intercultural Competence. Washington: Federation EIL, Washington University, Center for Social Development, 2006.

Gonzales-Davies, Maria. "The Role of Translation in Other Learning Contexts: Towards Acting Interculturally." Global Trends in Translator and Interpreter Training: Mediation and Culture. Ed. Séverine HubscherDavidson, and Michał Borodo. London: Bloomsbury, 2012. 161-180.

Hoffmann, Heinrich. Der Struwwelpeter. Renningen: Garant Verlag GmbH, 1845/2006.

Katan, David. Translating Cultures: An Introduction for Translators, Interpreters, and Mediators. Manchester: St. Jerome Publishing, 2004. 
Katan, David. "Intercultural mediation." Handbook of translation studies 4. Ed. Yves Gambier, and Luc van Doorslaer. Amsterdam: John Benjamins Publishing. 2013. 84-91.

Kecskes, Istvan. Intercultural pragmatics. Oxford: Oxford University Press, 2014.

Kiraly, David. A Social Constructivist Approach to Translator Education; Empowerment from Theory to Practice. Manchester: St. Jerome Publishing, 2000.

Kučiš, Vlasta. Translatologija u teoriji i praksi. Zagreb: Hrvatsko komunikološko društvo i Nonacom, 2016.

Lázár, Ildikó, et al. (eds.) Developing and Assessing Intercultural Communicative Competence: A Guide for Language Teachers and Teacher Educators. European Centre for Modern Languages. Strasbourg: Council of Europe, 2007.

Newmark, Peter. A Textbook of Translation. New York: Prentice Hall, 1995.

Spitzberger, Brian, Gabrielle Changnon. "Conceptualizing Intercultural Competence". The SAGE Handbook of Intercultural Competence. Ed. Darla K. Deardorff. Sage: Thousand Oaks, 2009. 2-52.

Pym, Anthony, et al. Translation and language learning: The role of translation in the teaching of languages in the European Union. Luxembourg: Publications Office of the European Union, 2013.

Toury, Gideon. Descriptive translation studies and beyond: Revised edition. Amsterdam: John Benjamins Publishing, 2012.

\section{INTERKULTURELLE KOMPETENZEN IN AUSBILDUNG ZUM ÜBERSETZER}

In dieser Abhandlung wird ein gemeinsames Studentenprojekt dargestellt, das im Rahmen von zwei Übersetzungslehrveranstaltungen an den Universitäten in Zadar (Kroatien) und Novi Sad (Serbien) realisiert wurde. In der vorliegenden Studie wurden folgende Ziele verfolgt: die studentische Teamarbeit, die sowohl an den Heimatuniversitäten als auch virtuell zwischen den Partneruniversitäten organisiert und durchgeführt wurde, sollte den Studierenden in den beiden Ländern helfen, die interkulturelle Kompetenz zu erwerben und zu stärken. Die sorgfältige Planung und Durchführung des Übersetzungsprojektes stellt dabei eine besondere organisatorische Herausforderung für die Studierenden dar. Interkulturelle Kompetenzen und Kooperationsfähigkeiten gehören zu den Kernkompetenzen eines professionellen Translators, aber es ist oft der Fall, dass diese Kompentenzen im Rahmen der universitären Übersetzerausbildung nicht ausreichend gefördert werden. Dieses Studentenprojekt sollte den Erwerb der grundlegenden übersetzerischen Kompetenzen unserer Studierenden unterstützen und zur Verbesserung ihrer Beschäftigungsfähigkeiten und Berufschancen beitragen. Diese qualitative und quantitative Studie basiert auf der Analyse des Übersetzungsprozesses in den studentischen Teams und auf der qualitativen Analyse ihrer Übersetzungen. 
Um die Daten für die hier vorgestellten Ergebnisse zu sammeln, wurden folgende Methoden verwendet: die Beobachtungen der Studierenden, Fragebögen und Analysen der Quell- und Zieltexte. Die Analyse ergibt außerordentliche Vorteile dieser Vorgehensweise, aber sie weist auch auf bestimmte Problembereiche hin, die in der Translatologie gelöst werden sollen.

Schlüsselwörter: Übersetzerausbildung, Mitarbeit, Teamarbeit, interkulturelle Kompetenzen, aufgabenorientierter Ansatz 